Check for updates

Cite this: RSC Adv., 2018, 8, 671

Received 15th October 2017

Accepted 24th November 2017

DOI: 10.1039/c7ra11364a

rsc.li/rsc-advances

\section{The effect of beta-sitosterol and its derivatives on depression by the modification of 5-HT, DA and GABA-ergic systems in mice}

\author{
Yongxia Yin, $\uparrow^{a}$ Xiaofeng Liu,,$^{b}$ Jinping Liu, $\uparrow^{\mathrm{c}}$ Enbo Cai, $\uparrow^{\mathrm{a}}$ Yan Zhao, (D) *a Haijun $\mathrm{Li}^{\mathrm{c}}$ \\ Lianxue Zhang, ${ }^{a}$ Pingya $\mathrm{Li}^{\mathrm{c}}$ and Yugang Gao*a
}

Beta-sitosterol belongs to the group of phytosterols, which are active trace components existing in natural plants, known as the "key of life", and have a steroid nucleus structure similar to cholesterol. Due to the insolubility issue of beta-sitosterol, most pharmacological studies and clinical applications are limited. Therefore, the modification of beta-sitosterol into its derivatives to enhance its pharmacologic activity is viable. In this study, 4 kinds of new beta-sitosterol derivative were obtained by an esterification reaction with beta-sitosterol, organic acids, EDCI and DMAP in dichloromethane. The chemical structures were defined by IR and NMR. Beta-sitosterol and its derivatives were used to carry out antidepressant research in the tail suspension test (TST) and the forced swimming test (FST) in mice. Additionally, the roles of different parts of the central nervous system (CNS) in the antidepressant-like effect of Sit-S, which is one of the beta-sitosterol derivatives, were also investigated. The results showed that the derivatives exhibited a stronger antidepressant activity than beta-sitosterol. Among the derivatives, administration of Sit-S ( $4 \mathrm{mg} \mathrm{kg}^{-1}$ ) gave the lowest immobility time in the TST, demonstrating that Sit-S exhibited the strongest antidepressant-like activity. The study into the roles of different parts of the CNS in the antidepressant-like effect of Sit-S showed that agomelatine $\left(40 \mathrm{mg} \mathrm{kg}^{-1}\right)$, haloperidol $\left(0.2 \mathrm{mg} \mathrm{kg}^{-1}\right)$ and bicuculline $\left(4 \mathrm{mg} \mathrm{kg}^{-1}\right)$ reversed the antidepressant effect of Sit-S $\left(4 \mathrm{mg} \mathrm{kg}^{-1}\right)$. This study confirmed the conclusions that beta-sitosterol derivatives broaden the pharmacological effects of beta-sitosterol, Sit-S ( $4 \mathrm{mg} \mathrm{kg}^{-1}$ ) exhibits antidepressant-like effects, and this antidepressant-like effect on male adult mice is mediated by the 5-HT, DA and GABA-ergic systems.

\section{Introduction}

Over the last few decades, depression has become one of the most major social health problems. ${ }^{1}$ According to the World Health Organization (WHO), depression, which is a prevalent psychiatric disorder with symptoms of sadness, loss of interest, lack of appetite, low self-esteem, insomnia and thoughts of suicide, is predicted to become the second leading cause of disability by the year $2020 .^{2}$ In the world today, its lifetime prevalence rate is about $15-17 \% .^{3}$ The mechanism of depression remains obscure, and depression is clinically complex, including different nervous system process. This complexity is a challenge for scientists seeking novel antidepressant drugs with characteristics of high efficiency and safe activity. ${ }^{4}$ Moreover, the monoamine hypothesis is the current industry

${ }^{a}$ College of Chinese Medicinal Materials, Jilin Agricultural University, Changchun 130118, Jilin, China. E-mail: zhaoyan@jlau.edu.cn; gaoyugang_2006@163.com; Fax: +86431 84533358; Tel: +8643184533358

${ }^{b}$ Ningxia People's Hospital, Yinchuan, China

'Jilin University, Changchun, China

$\dagger$ These authors contributed equally to this work. recognized mechanism of depression, in which monoamine neurotransmitters are majorly depleted in the central nervous system $(\mathrm{CNS})^{5}$ and patients with major depression have symptoms of abnormal performance of brain monoamine neurotransmitters, specifically serotonin (5-HT), norepinephrine (NA), dopamine (DA) and gamma-aminobutyric acid (GABA). ${ }^{6}$

The most widely used antidepressant drugs in modern society are chemical drugs, including monoamine oxidase inhibitors (MAOIs), selective noradrenaline reuptake inhibitors (SNRIs), selective serotonin reuptake inhibitors (SSRIs) and tricyclic antidepressants (TCAs). These drugs only improve some symptoms of depression on the surface, with severe side effects. ${ }^{7}$ Therefore, there is a considerable need to explore new types of therapies for depression which are natural, safe and effective.

Beta-sitosterol (Sit) belongs to the group of phytosterols, which mainly includes Sit, stigmasterol and campesterol, and phytosterols are essential steroid molecules that stabilize the phospholipid bilayers of cell membranes in plants, ${ }^{8}$ having similar structural and biological functions to cholesterol, ${ }^{9}$ and are a major group of bioactive constituents with well proven bioactivity. ${ }^{10}$ Phytosterols show a variety of health benefits in 
vivo, in particular protection against various chronic ailments, ${ }^{\mathbf{1 1}}$ such as cardiovascular diseases, ${ }^{12}$ diabetes, ${ }^{13}$ cancer ${ }^{14}$ and hepatic injury. ${ }^{15}$ It is worth mentioning that phytosterols have been attracting much interest because of their well-known cholesterol-lowering property recently. ${ }^{16}$ However, pure phytosterols have been proven to be crystalline powders with limited solubility in water or oil (1-2\% in water and $3-4 \%$ in oil), namely, they are insoluble in water and poorly soluble in oil and fat, and they even tend to form crystals in liquid media at higher concentrations. ${ }^{16}$ There is no doubt that the nature drastically limits the widespread application of phytosterols in the food, medical, cosmetic and other industries. To overcome this problem, many studies have focused on the chemical modification of phytosterol. ${ }^{17}$ This study follows this idea: the Sit chemical structure was modified by esterification and the antidepressant-like effects, their effects on neurotransmitter systems, and the mechanisms involved in the antidepressant effects of Sit have been investigated.

\section{Methods and materials}

\subsection{Animals}

Adult male ICR mice, weighing $18 \pm 2 \mathrm{~g}$, were supplied by the Changchun Yisi experimental animal technology Co., Ltd. The animals were maintained in standardized laboratory conditions (temperature $23 \pm 2{ }^{\circ} \mathrm{C}$, relative humidity $50 \pm 10 \%$ and a $12 \mathrm{~h}$ light/dark cycle with the light on at 7:00 a.m.) with food and tap water available ad libitum. After 1 week of acclimatization, all mice were randomly divided into different group $(n=10)$. All experiments were carried out in accordance with the Guide for Animal Experimentation of Jilin Agricultural University. The protocol was approved by the Jilin Agricultural University Institutional Animal Care and Use Committee.

\subsection{Drugs and reagents}

\subsubsection{Synthesis of compounds}

Materials. Sit, 2-tetrahydrofuroic acid, $N$-boc-L-phenylalanine, sorbic acid, salicylic acid, 4-dimethylaminopyridine (DMAP) and 1-ethylethyl-3-(3-dimethylaminopropyl) carbodiimide hydrochloride (EDCI) were purchased from Sigma (St. Louis, MO, USA).

Synthesis. According to the report, ${ }^{18}$ the synthesis of Sit derivatives with organic acids and Sit was as follows. The experimental procedure takes beta-sitosteryl salicylate (Sit-S) as an example. Salicylic acid $(41.4 \mathrm{mg})$ and Sit $(83.0 \mathrm{mg})$ were mixed in $5 \mathrm{~mL}$ dichloromethane. During the reaction, the water produced slows down or even stops the process and EDCI (76.8 $\mathrm{mg}$ ) was added to stop this side-effect during the process. After 10 minutes, DMAP (7.4 mg), used as a catalyst, was added. After the solution was heated to reflux for 6 hours, the dissolvent was removed under reduced pressure and then the residue was purified by silica gel chromatography and eluted with petroleum ether/dichloromethane/ethyl acetate $(7: 7: 1, \mathrm{v} / \mathrm{v})$ to yield Sit-S, which is a pale yellow oily colloid $(95.8 \mathrm{mg})$, and the purity of Sit-S (98.5\%) was determined by HPLC. The synthesis steps of the other three derivatives of Sit, beta-sitosteryl 2-tetrahydrofuroate (Sit-T), beta-sitosteryl $\mathrm{N}$-boc-L-phenylalaninate (Sit-P) and beta-sitosteryl sorbate (Sit-Sr), are similar to this, with a slight difference.

2.2.2 Structural identification. The structures of the Sit derivatives were established by IR and NMR analysis. The NMR spectra were recorded on a Varian Mercury $300 \mathrm{MHz}$ NMR spectrometer equipped with an Oxford Instruments Ltd. superconducting magnet (Palo Alto, CA, USA). FTIR analysis was performed in a WGH-30A double beam infrared spectrophotometer (Gangdong Sci. \& Tech. development Co., Ltd. Tianjin, China). The specific conclusion is described in detail in the Results section.

\subsection{Antidepressant drugs}

Fluoxetine (5 $\mathrm{mg} \mathrm{kg} \mathrm{kg}^{-1}, 20 \mathrm{mg} \mathrm{kg} \mathrm{kg}^{-1}$, an antidepressant drug belonging to the SSRI group), reboxetine $\left(2.5 \mathrm{mg} \mathrm{kg}^{-1}\right.$, $10 \mathrm{mg} \mathrm{kg}^{-1}$, an antidepressant drug belonging to the NA reuptake inhibitor group), para-chlorophenylalanine (100 $\mathrm{mg} \mathrm{kg}^{-1}$, a 5 -HT depressor), Im-hydrochloride $\left(20 \mathrm{mg} \mathrm{kg}^{-1}\right.$, an NA and 5 -HT reuptake inhibitor), agomelatine $\left(40 \mathrm{mg} \mathrm{kg}^{-1}\right.$, a 5-HT and 5-HT2C receptor antagonist), ondansetron ( $8 \mathrm{mg} \mathrm{kg}^{-1}$, a 5-HT reuptake inhibitor and a 5-HT3 receptor antagonist), bicuculline $\left(4 \mathrm{mg} \mathrm{kg}^{-1}\right.$, an antagonist of the inhibitory neurotransmitter GABA), haloperidol ( $0.2 \mathrm{mg} \mathrm{kg}^{-1}$, a non-selective D2 receptor antagonist), prazosin $\left(1 \mathrm{mg} \mathrm{kg}^{-1}\right.$, an $\alpha 1$-adrenoceptor antagonist), $N$-methyl-D-aspartic acid (NMDA, $75 \mathrm{mg} \mathrm{kg}^{-1}$, an agonist at the glutamate (Glu) site) and ramelteon $\left(16 \mathrm{mg} \mathrm{kg}^{-1}\right.$, a melatonin receptor agonist) were also from Sigma. The ELISA kits for the detection of GABA, 5-HT and DA were from US R\&D Systems, Ltd. (Minneapolis, USA). All other reagents used in this study were of analytical grade.

\subsection{Spontaneous locomotor activity test (SLT)}

In order to exclude the possibility that the alteration in the immobility time in the tail suspension test (TST) and the forced swimming test (FST) was due to the impact of the motorial activity, the spontaneous locomotor activity of each mouse was detected in a ZZ-6 mouse autonomic activity test instrument (Shanghai Gemma Medical Technology Development Co., Ltd., Shanghai, China). The total autonomous activity times of each mouse were measured over a 5 min period using an experimental video analysis system placed in a darkened and sound weakened testing room. ${ }^{19}$

\subsection{Tail suspension test (TST)}

The TST has been widely used as a screening assay for antidepressant drugs. ${ }^{20}$ The mice were suspended by their tails using an elastic band attached to the tail by adhesive tape, and the elastic band was hooked on a horizontal rod. Each mouse was visually isolated from the surrounding room by dark-colored cardboard, which was positioned at least $150 \mathrm{~mm}$ away from the mice. The distance between the heads of the mice and the floor was approximately $200 \mathrm{~mm}$. The behavior was recorded for a 6 min period with a digital camera, and the duration of immobility of the mouse limbs within the last 4 min was 
measured. The longer the immobility time of the mouse, the more depressed it feels.

\subsection{Forced swimming test (FST)}

The FST was performed to evaluate the behavioral despair of the mice, which is regarded as a standard rodent test for screening the antidepressant activity of drugs. Mice were separately placed in an open cylindrical glass bottle (diameter $10 \mathrm{~cm}$ and height $25 \mathrm{~cm}$ ) containing $20 \mathrm{~cm}$ of water at $24 \pm 2{ }^{\circ} \mathrm{C}$. Each mouse was regarded as immobile only when it stopped struggling and floated on the surface of the water. The behavior was measured for a 6 min period, and the duration of immobility within the last $4 \mathrm{~min}$ was recorded. The longer the immobility time of the mouse, the more depressed it feels. ${ }^{21}$

\subsection{Drug treatment}

The tested materials (Sit and its derivatives) were dissolved in soybean oil, whereas all the other drugs were dissolved in an isotonic saline solution $(0.9 \% \mathrm{NaCl} \mathrm{aq})$ immediately before use. The treatments were administered to all the tested mice by the intraperitoneal injection (i.p.) route before the behavior tests (SLT, TST and FST). The observers were blind to the drug treatment. Specific tests were designed as follows.

2.7.1 The antidepressant effect of Sit and its derivatives in the TST and FST. The tested drugs including Sit, Sit-T, Sit-P, SitSr, Sit-S (0.1 $\mathrm{mg} \mathrm{kg}^{-1}$ to $100 \mathrm{mg} \mathrm{kg}^{-1}$, respectively) were injected and the immobility time was recorded $60 \mathrm{~min}$ after administration.

2.7.2 The effective and sub-effective dosage of Sit-S in the TST. Positive drug groups (sub-effective dose): fluoxetine $\left(5 \mathrm{mg} \mathrm{kg}{ }^{-1}\right)$ and reboxetine $\left(2.5 \mathrm{mg} \mathrm{kg}^{-1}\right)$ were administered $60 \mathrm{~min}$ before the TST. Sit-S groups: Sit-S $\left(0.5 \mathrm{mg} \mathrm{kg} \mathrm{kg}^{-1}\right.$, $1 \mathrm{mg} \mathrm{kg}^{-1}, 2 \mathrm{mg} \mathrm{kg}^{-1}, 4 \mathrm{mg} \mathrm{kg}^{-1}$ and $6 \mathrm{mg} \mathrm{kg}^{-1}$ ) was administered $60 \mathrm{~min}$ before the TST. Positive drugs + Sit-S group: fluoxetine $\left(5 \mathrm{mg} \mathrm{kg}^{-1}\right)$ and reboxetine $\left(2.5 \mathrm{mg} \mathrm{kg} \mathrm{kg}^{-1}\right)$ were administered immediately after the administration of Sit-S $\left(1 \mathrm{mg} \mathrm{kg}^{-1}\right) 60 \mathrm{~min}$ prior to the experiment.

2.7.3 The roles of different CNS functions in the antidepressant-like effect of Sit-S in the TST. Control group: the same volume of soybean oil (i.p.) was administered 60 min prior to the experiment.

p-Chlorophenylalanine group: $p$-chlorophenylalanine (100 $\mathrm{mg} \mathrm{kg}^{-1}$, i.p.) was administered $60 \mathrm{~min}$ prior to the experiment; Sit-S (4 mg kg-1, i.g.) + $p$-chlorophenylalanine group: $p$-chlorophenylalanine $\left(100 \mathrm{mg} \mathrm{kg}^{-1}\right.$, i.p.) was administered $30 \mathrm{~min}$ prior to Sit-S (4 $\mathrm{mg} \mathrm{kg}^{-1}$, i.g.), and the behavioral experiment was performed after $60 \mathrm{~min}$.

Im-hydrochloride group: Im-hydrochloride $\left(20 \mathrm{mg} \mathrm{kg}^{-1}\right.$, i.p.) was administered $60 \mathrm{~min}$ prior to the experiment; Sit-S (4 mg kg ${ }^{-1}$, i.g.) + Im-hydrochloride group: Im-hydrochloride (20 $\mathrm{mg} \mathrm{kg}^{-1}$, i.p.) was administered $30 \mathrm{~min}$ prior to Sit-S (4 $\mathrm{mg} \mathrm{kg}^{-1}$, i.g.), and the behavioral experiment was performed after $60 \mathrm{~min}$.

Agomelatine group: agomelatine (40 $\mathrm{mg} \mathrm{kg}^{-1}$, i.p.) was administered 60 min prior to the experiment; Sit-S (4 mg kg${ }^{-1}$, i.g.) + agomelatine group: agomelatine (40 $\mathrm{mg} \mathrm{kg}^{-1}$, i.p.) was administered $30 \mathrm{~min}$ prior to Sit-S ( $4 \mathrm{mg} \mathrm{kg}{ }^{-1}$, i.g.), and the behavioral experiment was performed after $60 \mathrm{~min}$.

Ondansetron group: ondansetron ( $8 \mathrm{mg} \mathrm{kg}^{-1}$, i.p.) was administered $60 \mathrm{~min}$ prior to the experiment; Sit-S (4 mg kg-1, i.g.) + ondansetron group: ondansetron ( $8 \mathrm{mg} \mathrm{kg}^{-1}$, i.p.) was administered $30 \mathrm{~min}$ prior to Sit-S ( $4 \mathrm{mg} \mathrm{kg}^{-1}$, i.g.), and the behavioral experiment was performed after $60 \mathrm{~min}$.

Bicuculline group: bicuculline $\left(4 \mathrm{mg} \mathrm{kg}^{-1}\right.$, i.p.) was administered $60 \mathrm{~min}$ prior to the experiment; Sit-S (4 $\mathrm{mg} \mathrm{kg}^{-1}$, i.g.) + bicuculline group: bicuculline $\left(4 \mathrm{mg} \mathrm{kg}^{-1}\right.$, i.p.) was administered $30 \mathrm{~min}$ prior to Sit-S $\left(4 \mathrm{mg} \mathrm{kg}^{-1}\right.$, i.g.), and the behavioral experiment was performed after $60 \mathrm{~min}$.

Haloperidol group: haloperidol (0.2 $\mathrm{mg} \mathrm{kg}^{-1}$, i.p.) was administered $60 \mathrm{~min}$ prior to the experiment; Sit-S (4 mg kg ${ }^{-1}$, i.g.) + haloperidol group: haloperidol $\left(0.2 \mathrm{mg} \mathrm{kg}^{-1}\right.$, i.p.) was administered $30 \mathrm{~min}$ prior to Sit-S ( $4 \mathrm{mg} \mathrm{kg}^{-1}$, i.g.), and the behavioral experiment was performed after $60 \mathrm{~min}$.

Prazosin group: prazosin $\left(1 \mathrm{mg} \mathrm{kg}^{-1}\right.$, i.p.) was administered $60 \mathrm{~min}$ prior to the experiment; Sit-S $\left(4 \mathrm{mg} \mathrm{kg}^{-1}\right.$, i.g. $)+$ prazosin group: prazosin ( $1 \mathrm{mg} \mathrm{kg}^{-1}$, i.p.) was administered $30 \mathrm{~min}$ prior to Sit-S (4 $\mathrm{mg} \mathrm{kg}^{-1}$, i.g.), and the behavioral experiment was performed after $60 \mathrm{~min}$.

NMDA group: NMDA (75 $\mathrm{mg} \mathrm{kg}{ }^{-1}$, i.p.) was administered $60 \mathrm{~min}$ prior to the experiment. Sit-S $\left(4 \mathrm{mg} \mathrm{kg}^{-1}\right.$, i.p. $)+$ NMDA (75 $\mathrm{mg} \mathrm{kg}^{-1}$, i.p.) group: NMDA was administered $30 \mathrm{~min}$ prior to Sit-S, and the behavioral experiment was performed after $60 \mathrm{~min}$.

Ramelteon group: ramelteon (16 $\mathrm{mg} \mathrm{kg}^{-1}$, i.p.) was administered $60 \mathrm{~min}$ prior to the experiment; Sit-S $\left(4 \mathrm{mg} \mathrm{kg}^{-1}\right.$, i.g. $)+$ ramelteon group: ramelteon $\left(16 \mathrm{mg} \mathrm{kg}^{-1}\right.$, i.p.) was administered $30 \mathrm{~min}$ prior to Sit-S (4 $\mathrm{mg} \mathrm{kg} \mathrm{kg}^{-1}$, i.g.), and the behavioral experiment was performed after $60 \mathrm{~min}$.

\subsection{Biochemical measurements}

The mice brains were washed with ice-cold physiological saline and homogenized, shaken for $10 \mathrm{~s}$ and centrifuged at $12000 \times$ $g$ for $5 \mathrm{~min}$ at $4{ }^{\circ} \mathrm{C}$. The supernatants were collected for the detection of GABA, DA and 5-HT by the commercially available ELISA kits (JianCheng, NanJing, China), and specific operating steps were carried out following the instructions.

\subsection{Statistical analyses}

All data were indicated using mean \pm S.D. One-way analysis of variance was shown for multiple comparisons. Using the $t$-test to analyze the treatment effects, a value of $p<0.05$ was considered to be statistically significantly for analysis.

\section{Results}

\subsection{Structural identification}

In this study, two methods (IR and NMR) were used to identify the molecular structures of the newly synthesized compounds and the information is shown in Fig. 1.

\subsubsection{Sit-T}

IR spectrum. $2964-2888 \mathrm{~cm}^{-1}$ is the telescopic vibration peak $\left(\nu_{\mathrm{CH}}\right)$ of saturated alkanes, demonstrating the existence of 


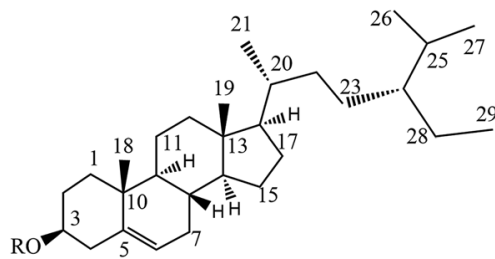

Fig. 1 The chemical structures of beta-sitosterol and its derivatives.
Sit: $\mathrm{R}=\mathrm{H}$

Sit-T: R=tetrahydrofuran-2-carbonyl

Sit-P: $\mathrm{R}=(S)-2-(($ tert-butoxycarbonyl)amino)-3-phenylpropanoyl

Sit-Sr: $\mathrm{R}=(2 E, 4 E)$-hexa-2,4-dienoyl

Sit-S: R=2-hydroxybenzoyl saturated alkanes. The elongation vibration peak $\left(\nu_{\mathrm{C}=\mathrm{O}}\right)$ of the carbonyl group is shown at $1738 \mathrm{~cm}^{-1}$, indicating that there is a carbonyl group in the compound. $1629 \mathrm{~cm}^{-1}$ is $\nu_{\mathrm{C}=\mathrm{C}}$, indicating the existence of $\mathrm{C}=\mathrm{C} .1384 \mathrm{~cm}^{-1}$ and $1372 \mathrm{~cm}^{-1}$ are the deformation vibration peaks of the methyl group $\left(\delta_{\mathrm{CH}_{3}}\right)$.

NMR signal. ${ }^{1} \mathrm{H}$ NMR $\left(300 \mathrm{MHz}, \mathrm{CDCl}_{3}\right) \delta \mathrm{ppm}: 5.377(\mathrm{~d}, 1 \mathrm{H}$, $J=4.8 \mathrm{~Hz}, 6-\mathrm{H}), 4.681$ (m, 1H, 2"-H), 4.433 (m, 1H, 3-H), 4.025 (dd, $\left.1 \mathrm{H}, J=7.2,14.4 \mathrm{~Hz}, 5^{\prime \prime}-\mathrm{Ha}\right), 3.940\left(\mathrm{~m}, 1 \mathrm{H}, 5^{\prime \prime}-\mathrm{Hb}\right), 1.010$ (s, $\left.3 \mathrm{H}, 10-\mathrm{CH}_{3}\right), 0.922\left(\mathrm{~d}, 3 \mathrm{H}, 2^{\prime}-\mathrm{CH}_{3}\right), 0.859\left(\mathrm{t}, 3 \mathrm{H}, 5^{\prime}-\mathrm{CH}_{3}\right), 0.813$ $\left(\mathrm{d}, 6^{\prime}, 6^{\prime}-\mathrm{CH}_{3}\right), 0.668\left(\mathrm{~s}, 3 \mathrm{H}, 13-\mathrm{CH}_{3}\right)$. The signals at 2.343-0.753 are due to the hydrogenation on the other saturated carbons of the steroid nucleus and the 17 side chains and 2-tetrahydrofuroic acid.

${ }^{13} \mathrm{C}$ NMR $\left(75 \mathrm{MHz}, \mathrm{CDCl}_{3}\right) \delta \mathrm{ppm:} 172.67\left(\mathrm{C1}^{\prime}\right), 139.41$ (C5), 122.68 (C6), $76.79\left(\mathrm{C2}^{\prime \prime}\right), 74.33$ (C3), 69.17 (C5"), 56.63 (C14), 56.01 (C17), 49.99 (C9), 45.82 (C24), 42.25 (C13), 39.67 (C12), 37.95 (C4), 36.89 (C1), 36.51 (C10), 36.06 (C20), 33.91 (C22), 31.81 (C3"), 30.12 (C7,8), 29.16 (C25), 28.13 (C2), 27.63 (C23), 26.13 (C15), 25.09 (C4"), 24.20 (C16), 23.04 (C28), 20.96 (C11), 19.70 (C26), 19.20 (C27), 18.98 (C21), 18.70 (C18), 11.89 (C29), 11.76 (C19).

\subsubsection{Sit-P}

IR spectra. The peak at $3450 \mathrm{~cm}^{-1}$ is the telescopic vibration peak $\left(\nu_{\mathrm{NH}}\right)$ of the amino nitrogen hydrogen bond, and the peak at $3044 \mathrm{~cm}^{-1}$ is the telescopic vibration peak $\left(\nu_{\mathrm{CH}}\right)$ of the $=\mathrm{CH}$. The telescopic vibration peaks $\left(\nu_{\mathrm{C}=\mathrm{O}}\right)$ of the carbonyl group are at $1734 \mathrm{~cm}^{-1}$ and $1722 \mathrm{~cm}^{-1} .1670 \mathrm{~cm}^{-1}$ is $\nu_{\mathrm{C}=\mathrm{C}}$, indicating the existence of $\mathrm{C}=\mathrm{C}$. The signals at $1574 \mathrm{~cm}^{-1}$ and $1496 \mathrm{~cm}^{-1}$ are the signals of the telescopic vibration of the $\mathrm{C}=\mathrm{C}$ bond matrix in the benzene ring. $1384 \mathrm{~cm}^{-1}$ and $1370 \mathrm{~cm}^{-1}$ are the deformation vibration peaks of the methyl group $\left(\delta_{\mathrm{CH}_{3}}\right)$.

NMR signal. ${ }^{1} \mathrm{H}$ NMR $\left(300 \mathrm{MHz}, \mathrm{CDCl}_{3}\right) \delta \mathrm{ppm}: 7.311(\mathrm{~m}, 2 \mathrm{H}$, $\left.3^{\prime}, 5^{\prime}-\mathrm{H}\right), 7.276\left(\mathrm{~m}, 2 \mathrm{H}, 2^{\prime}, 6^{\prime}-\mathrm{H}\right), 7.140\left(\mathrm{~m}, 1 \mathrm{H}, 4^{\prime}-\mathrm{H}\right), 5.371(\mathrm{~d}, 1 \mathrm{H}$, $J=4.8 \mathrm{~Hz}, 6-\mathrm{H}), 5.034\left(\mathrm{~d}, 1 \mathrm{H}, J=8.1 \mathrm{~Hz}, 2^{\prime}-\mathrm{NH}\right), 4.642(\mathrm{~m}, 1 \mathrm{H}, 3-$ $\mathrm{H}), 3.080\left(\mathrm{~m}, 1 \mathrm{H}, 2^{\prime}-\mathrm{H}\right), 1.416\left(\mathrm{~s}, 3 \mathrm{H}, 1^{\prime \prime \prime \prime}-\left(\mathrm{CH}_{3}\right)_{3}\right), 1.001(\mathrm{~s}, 3 \mathrm{H}$, $18-\mathrm{H}), 0.936(\mathrm{~d}, 3 \mathrm{H}, J=6.6 \mathrm{~Hz}, 21-\mathrm{H}), 0.873(\mathrm{t}, 3 \mathrm{H}, J=7.2 \mathrm{~Hz}, 29-$ $\mathrm{H}), 0.828$ (d, 6H, $J=6.6 \mathrm{~Hz}, 26,27-\mathrm{H}), 0.679$ (s, 3H, 19-H). The signals at 2.383-0.767 are the hydrogen signals from the 2-tertbutylcarbonyl aminophenylpropionic acid group, the mother steroid nucleus and the other saturated carbons of the 17 side chains.

${ }^{13} \mathrm{C}$ NMR $\left(75 \mathrm{MHz}, \mathrm{CDCl}_{3}\right) \delta \mathrm{ppm}: 171.14\left(\mathrm{C1}^{\prime}\right), 154.98\left(\mathrm{C1}^{\prime \prime \prime}\right)$, 139.30 (C5), $136.06\left(\mathrm{C} 1^{\prime \prime}\right), 129.36\left(\mathrm{C}^{\prime \prime}, 5^{\prime \prime}\right), 128.34\left(\mathrm{C} 2^{\prime \prime}, 6^{\prime \prime}\right)$, 126.82 (C4"), 122.78 (C6), 79.62 (C1"'I'), 73.52 (C3), 56.59 (C14), 55.95 (C17), 54.46 (C2'), 49.92 (C9), 45.74 (C24), 42.22 (C13), 39.63 (C12), 37.83 (C4), 36.91 (C3'), 36.82 (C1), 36.47 (C10), 36.07 (C20), 33.85 (C22), 31.81 (C7), 31.76 (C8), 29.07 (C25), 28.23
$\left(\mathrm{C} 1^{\prime \prime \prime \prime}-\left(\mathrm{CH}_{3}\right)_{3}\right), 28.17$ (C2), 27.59 (C23), 25.99 (C15), 24.21 (C16), 22.99 (C28), 20.94 (C11), 19.76 (C26), 19.20 (C27), 18.98 (C21), 18.71 (C18), 11.91 (C29), 11.78 (C19).

\subsubsection{Sit-Sr}

IR spectrum. $3075 \mathrm{~cm}^{-1}$ is the stretching vibration peak $\left(\nu_{\mathrm{CH}}\right)$ of the $=\mathrm{CH}$ bond. $2975-2877 \mathrm{~cm}^{-1}$ is the stretching vibration peak ( $\nu_{\mathrm{CH}}$ ) of the $\mathrm{CH}_{3}$ bond. $1733 \mathrm{~cm}^{-1}$ is the stretching vibration peak $\left(\nu_{\mathrm{C}=\mathrm{O}}\right)$ of the carbonyl group and $1644 \mathrm{~cm}^{-1}$ is $\nu_{\mathrm{C}=\mathrm{C}}$, indicating the presence of $\mathrm{C}=\mathrm{C}$ bonds. $1383 \mathrm{~cm}^{-1}$ and $1369 \mathrm{~cm}^{-1}$ are the deformation vibration peaks $\left(\delta_{\mathrm{CH}_{3}}\right)$.

NMR signal. ${ }^{1} \mathrm{H}$ NMR $\left(300 \mathrm{MHz}, \mathrm{CDCl}_{3}\right) \delta \mathrm{ppm}: 7.259(\mathrm{dd}, 1 \mathrm{H}$, $\left.J=9.9,15.3 \mathrm{~Hz}, 3^{\prime}-\mathrm{H}\right), 6.213\left(\mathrm{dd}, 1 \mathrm{H}, J=9.9,15.3 \mathrm{~Hz}, 4^{\prime}-\mathrm{H}\right)$, $5.759\left(\mathrm{~d}, 1 \mathrm{H}, J=15.3 \mathrm{~Hz}, 2^{\prime}-\mathrm{H}\right), 5.367(\mathrm{~m}, 1 \mathrm{H}, 6-\mathrm{H}), 5.357(\mathrm{~m}, 1 \mathrm{H}$, $\left.5^{\prime}-\mathrm{H}\right), 4.675(\mathrm{~m}, 1 \mathrm{H}, 3-\mathrm{H}), 1.839\left(\mathrm{~d}, 3 \mathrm{H}, J=5.7 \mathrm{~Hz}, 6^{\prime}-\mathrm{H}\right), 1.011(\mathrm{~s}$, $3 \mathrm{H}, 18-\mathrm{H}), 0.914(\mathrm{~d}, 3 \mathrm{H}, J=6.3 \mathrm{~Hz}, 21-\mathrm{H}), 0.851(\mathrm{t}, 3 \mathrm{H}, J=$ $7.2 \mathrm{~Hz}, 29-\mathrm{H}), 0.806$ (d, 6H, $J=6.6 \mathrm{~Hz}, 26,27-\mathrm{H}), 0.661$ (s, 3H, 19$\mathrm{H})$. The signals at $2.347-0.745$ are the signals of the steroid nucleus and the other saturated carbons of the 17 side chains.

${ }^{13} \mathrm{C}$ NMR $\left(75 \mathrm{MHz}, \mathrm{CDCl}_{3}\right) \delta \mathrm{ppm}: 166.67(\mathrm{C}=\mathrm{O}), 144.68$ (C3'), 139.70 (C5), 139.00 (C5'), 129.77 (C4'), $122.54(\mathrm{C} 6), 119.43$ (C2'), 73.67 (C3), 56.64 (C14), 55.98 (C17), 49.98 (C9), 45.78 (C24), 42.26 (C13), 39.68 (C12), 38.17 (C4), 36.98 (C1), 36.57 (C10), 36.11 (C20), 33.88 (C22), 31.86 (C7), 31.82 (C8), 29.09 (C25), 28.21 (C2), 27.82 (C23), 26.01 (C15), 24.25 (C16), 23.01 (C28), 20.98 (C11), 19.78 (C26), 19.29 (C27), 18.99 (C21), 18.73 (C18), 18.60 (C6'), 11.94 (C29), 11.81(C19).

\subsubsection{Sit-S}

IR spectrum. $3450 \mathrm{~cm}^{-1}$ is the stretching vibration peak $\left(\nu_{\mathrm{OH}}\right)$ of the hydroxyl group. $3080 \mathrm{~cm}^{-1}$ is the hydrocarbon stretching vibration peak $\left(\nu_{\mathrm{ArCH}}\right)$ of the benzene ring. $2964-2876 \mathrm{~cm}^{-1}$ is the stretching vibration peak $\left(\nu_{\mathrm{CH}}\right)$ of the $\mathrm{CH}_{3}$ bonds. $1724 \mathrm{~cm}^{-1}$ is the stretching vibration peak of the carbonyl group $\left(\nu_{\mathrm{C}=\mathrm{O}}\right)$. $1614 \mathrm{~cm}^{-1}$ is for $\nu_{\mathrm{C}=\mathrm{C}}$, indicating the presence of $\mathrm{C}=\mathrm{C}$ bonds. $1604 \mathrm{~cm}^{-1}$ and $1582 \mathrm{~cm}^{-1}$ are the stretching vibration peaks $\left(\nu_{\mathrm{ArC}=\mathrm{C}}\right)$ of the benzene ring $\mathrm{C}=\mathrm{C}$ skeleton. $1384 \mathrm{~cm}^{-1}$ and $1372 \mathrm{~cm}^{-1}$ are deformed vibration peaks $\left(\delta_{\mathrm{CH}_{3}}\right)$ of the methyl group.

NMR signal. ${ }^{1} \mathrm{H}$ NMR $\left(300 \mathrm{MHz}, \mathrm{CDCl}_{3}\right) \delta \mathrm{ppm}: 10.836(\mathrm{~s}, 1 \mathrm{H}$, $\left.2^{\prime \prime}-\mathrm{H}\right), 7.781\left(\mathrm{dd}, 1 \mathrm{H}, J=1.5,7.8 \mathrm{~Hz}, 6^{\prime \prime}-\mathrm{H}\right), 7.377(\mathrm{dt}, 1 \mathrm{H}, J=1.5$, $\left.7.8 \mathrm{~Hz}, 5^{\prime \prime}-\mathrm{H}\right), 6.896\left(\mathrm{dd}, 1 \mathrm{H}, J=0.9,8.4 \mathrm{~Hz}, 3^{\prime \prime}-\mathrm{H}\right), 6.807(\mathrm{dt}, 1 \mathrm{H}$, $\left.J=0.9,8.4 \mathrm{~Hz}, 4^{\prime \prime}-\mathrm{H}\right), 5.356(\mathrm{~d}, 1 \mathrm{H}, J=4.5 \mathrm{~Hz}, 6-\mathrm{H}), 4.818(\mathrm{~m}$, $1 \mathrm{H}, 3-\mathrm{H}), 0.988\left(\mathrm{~s}, 3 \mathrm{H}, 10-\mathrm{CH}_{3}\right), 0.864\left(\mathrm{~d}, 3 \mathrm{H}, 2^{\prime}-\mathrm{CH}_{3}\right), 0.798(\mathrm{t}$, $\left.3 \mathrm{H}, 5^{\prime}-\mathrm{CH}_{3}\right), 0.752\left(\mathrm{~d}, 6^{\prime}, 6^{\prime}-\mathrm{CH}_{3}\right), 0.612\left(\mathrm{~s}, 3 \mathrm{H}, 13-\mathrm{CH}_{3}\right)$. The signals at $2.403-0.630$ are the signal of the steroid nucleus and the other saturated carbons of the 17 side chains.

${ }^{13} \mathrm{C}$ NMR $\left(75 \mathrm{MHz}, \mathrm{CDCl}_{3}\right) \delta$ ppm: $168.60\left(1^{\prime}\right), 160.76\left(\mathrm{C2}^{\prime \prime}\right)$, 138.30 (C5), $134.39\left(\mathrm{C} 4^{\prime \prime}\right), 128.86\left(\mathrm{C6}^{\prime \prime}\right), 122.08$ (C6), 117.90 
(C5"), $116.51\left(\mathrm{C}^{\prime \prime}\right), 111.90\left(\mathrm{C1}^{\prime \prime}\right), 74.26$ (C3), 55.70 (C14), 55.11 (C17), 49.09 (C9), 44.89 (C24), 421.34 (C13), 38.75 (C12), 37.11 (C4), 35.99 (C1), 35.64 (C10), 35.15 (C20), 32.99 (C22), 30.93 (C7), 30.89 (C8), 28.25 (C25), 27.23 (C2), 26.80 (C23), 25.22 (C15), 23.30 (C16), 22.12 (C28), 20.07 (C11), 18.80 (C26), 18.33 (C27), 18.08 (C21), 17.80 (C18), 10.99 (C29), 10.86 (C19).

\subsection{The antidepressant effect of Sit and its derivatives in the TST and FST}

The antidepressant-like activities of Sit and its derivatives were screened for a wide dose range $\left(0.1 \mathrm{mg} \mathrm{kg}^{-1}\right.$ to $\left.100 \mathrm{mg} \mathrm{kg}^{-1}\right)$. The experiment found that Sit and its derivatives displayed antidepressant-like activity against the depressant mouse model. At the same time, the effective dose of Sit and its derivatives is between $1-20 \mathrm{mg} \mathrm{kg}^{-1}$. Sit-S exhibited a stronger antidepressant-like activity compared to other drugs in the TST and FST, and so Sit-S was chosen to carry out subsequent experiments. The details were shown in Fig. 2.

It is shown in Fig. 2 that the immobility time of the mice in the TST is more sensitive to the treatment than that in the FST, indicating that the TST is more advantageous than the FST to screen for antidepressant activity. Moreover, for Sit and its derivatives, a dose of $2.5 \mathrm{mg} \mathrm{kg}{ }^{-1}$ gives the most beneficial antidepressant-like effect: different doses of different drugs exhibited different antidepressant activities in different models and the optimal antidepressant activity occurred for Sit-S (2.5 $\mathrm{mg} \mathrm{kg}^{-1}$ ). Next, the optimal effective dose and subeffective dose of Sit-S were screened in the TST.

\subsection{The effective and sub-effective doses of Sit-S in the TST}

The effective and sub-effective doses of Sit-S were obtained with $2.5 \mathrm{mg} \mathrm{kg}^{-1}$ as the mean, and meanwhile, the autonomous activity test was added in order to exclude the false positive effect in the mice behavioral despair tests. The detailed results are shown in Fig. 3.

From Fig. 3(A), when the dose of Sit-S reached $1 \mathrm{mg} \mathrm{kg}{ }^{-1}$, the mouse's immobility time in the TST was slightly decreased, however, when the dose was $4 \mathrm{mg} \mathrm{kg}^{-1}$, Sit-S significantly reduced the immobility time of the mice in the
TST. Therefore, $4 \mathrm{mg} \mathrm{kg}^{-1}$ and $1 \mathrm{mg} \mathrm{kg}^{-1}$ were chosen as the effective and sub-effective doses, respectively. From Fig. 3(B), compared to the control group, Sit-S didn't change the spontaneous activity in the autonomous activity test and the result indicates that Sit-S didn't affect the spontaneous activity of the mice.

\subsection{The antidepressant effect of co-administration of antidepressant drugs with sub-effective doses of Sit-S in the TST}

Many studies have demonstrated that combined treatment with commonly used antidepressant drugs might bring about a better treatment effect than monotheraphy. ${ }^{23}$ After obtaining the sub-effective dose of Sit-S, the effect of introducing a commercially accepted positive drug with a good therapeutic effect on depression (fluoxetine and reboxetine) on the antidepressant-like effect of Sit-S was compared with the antidepressant-like effect of Sit-S alone and the results are shown in Fig. 4.

The results in Fig. 4 show that the experimental groups reduced the immobility time of the mice compared with the control group and at the same time the co-administration of fluoxetine (5 $\mathrm{mg} \mathrm{kg}^{-1}$, i.p.) with a sub-effective dose of Sit-S (1 $\mathrm{mg} \mathrm{kg}^{-1}$, i.p.), or of reboxetine $\left(2.5 \mathrm{mg} \mathrm{kg}^{-1}\right.$, i.p.) with Sit-S (1 $\mathrm{mg} \mathrm{kg} \mathrm{kg}^{-1}$, i.p.), significantly reduced the immobility time compared with treatment with either of those substances alone or the control group.

\subsection{The role of different functions of the CNS in the antidepressant-like effect of Sit-S in the TST}

In this experiment, 8 different kinds of antidepressant, affecting different functions in the CNS, were introduced (mentioned in the methods and materials section) and 3 of them were found to play an important role in the antidepressant effect of Sit-S in the TST. They are agomelatine (40 $\mathrm{mg} \mathrm{kg}^{-1}$, i.p.), haloperidol (0.2 $\mathrm{mg} \mathrm{kg}^{-1}$, i.p.) and bicuculline ( $4 \mathrm{mg} \mathrm{kg}^{-1}$, i.p.). Significant data results are presented in Fig. 5.

Fig. 5(A) shows that pre-treatment with agomelatine (40 $\mathrm{mg} \mathrm{kg}^{-1}$, i.p, a 5-HT and 5-HT2C receptor antagonist)
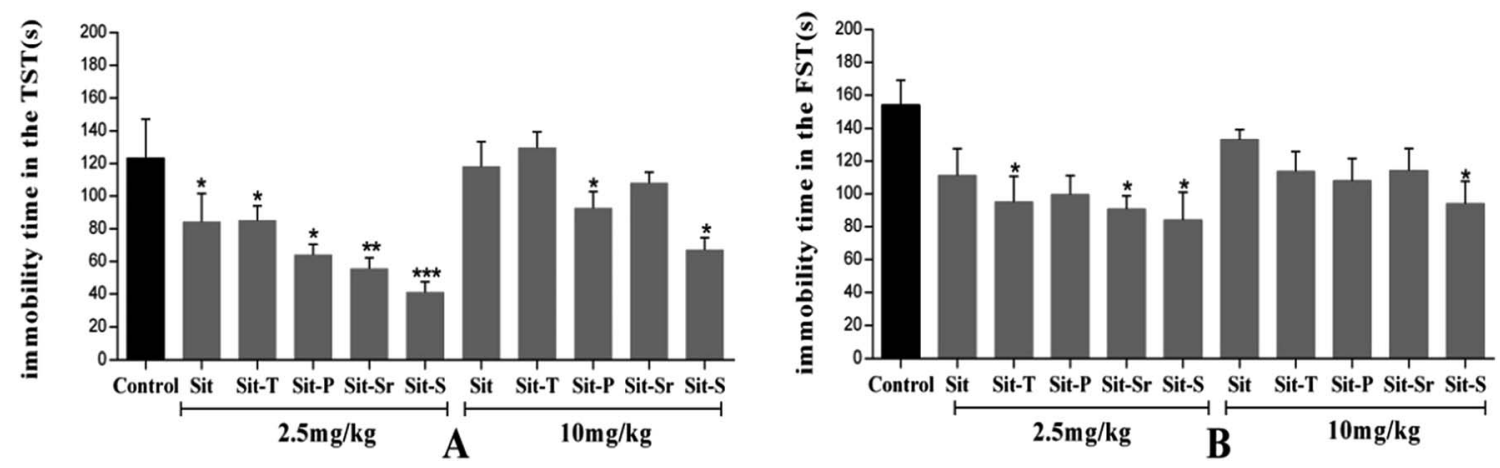

Fig. 2 (A) shows the antidepressant-like effect of different doses of Sit and its derivatives in the TST and (B) shows the antidepressant-like effect of different doses of Sit and its derivatives in the FST. The values represent the mean \pm SD ( $n=10$ in each group), compared with the control group, $* p<0.05, * * p<0.01$ and $* * * p<0.001$. 


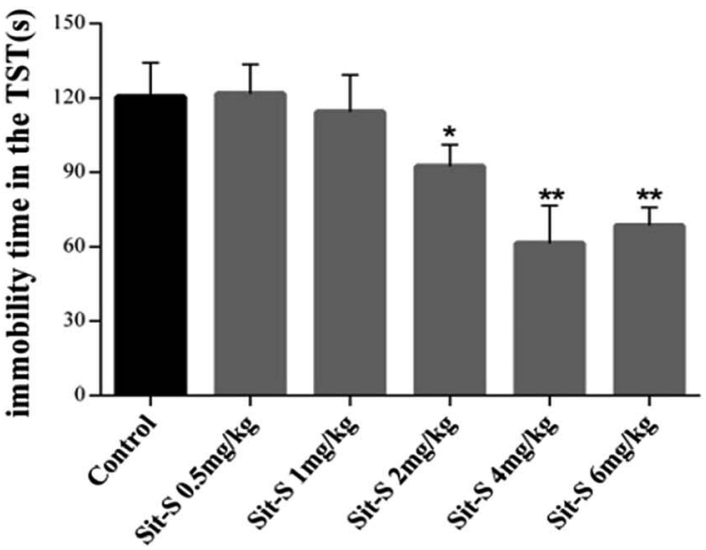

A

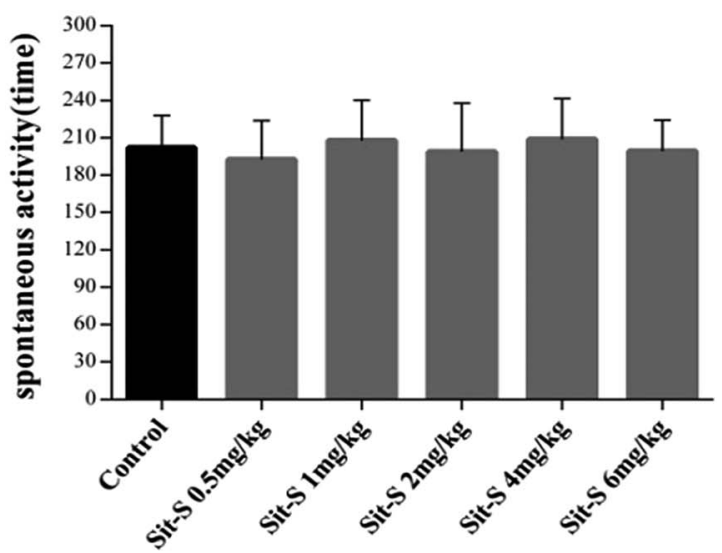

B

Fig. 3 (A) shows the antidepressant-like effect of different doses of Sit-S in the TST and (B) shows the manifestation of the different doses of Sit-S in the autonomous activities. The values represent the mean \pm SD ( $n=10$ in each group), compared with the control group, *p<0.05 and $* * p<$ 0.01 .

significantly increased the immobility time compared with Sit-S (4 $\mathrm{mg} \mathrm{kg}^{-1}$, i.p.) treatment alone in the TST, indicating that agomelatine markedly reduced the Sit-S $\left(4 \mathrm{mg} \mathrm{kg}^{-1}\right.$, i.p.) antidepressant effect. Fig. 5(B) shows that pre-treatment with haloperidol $\left(0.2 \mathrm{mg} \mathrm{kg}^{-1}\right.$, i.p, a nonselective D2 receptor antagonist) significantly reduced the antidepressant-like effect induced by Sit-S (4 $\mathrm{mg} \mathrm{kg}^{-1}$, i.p.). Fig. 5(C) shows that pretreatment with bicuculline $\left(4 \mathrm{mg} \mathrm{kg}{ }^{-1}\right.$, i.p, an antagonist of the inhibitory neurotransmitter GABA) slightly increased the immobility time compared to that for Sit-S $\left(4 \mathrm{mg} \mathrm{kg}^{-1}\right.$, i.p. $)$ alone in the TST, indicating that bicuculline could slightly reduce the Sit-S (4 $\mathrm{mg} \mathrm{kg}^{-1}$, i.p.) antidepressant effect.

\subsection{Effects of Sit-S on the levels of 5-HT, DA and GABA in mice exposed to the TST}

The effects of co-treatment of Sit-S with agomelatine, haloperidol and bicuculline on the 5-HT, DA and GABA levels in the brains of mice in the TST are shown in Fig. 6. According to Fig. 6(A), the experiment indicated that agomelatine $\left(40 \mathrm{mg} \mathrm{kg}^{-1}\right.$ ), as a 5 -HT and 5-HT2C receptor antagonist, resulted in the 5-HT level in the mouse brain being decreased significantly compared to that of the Sit-S group; according to Fig. 6(B), the experiment made it clear that haloperidol $\left(0.2 \mathrm{mg} \mathrm{kg}^{-1}\right)$, as a non-selective D2 receptor antagonist, led to the DA level in the mouse brain being obviously decreased

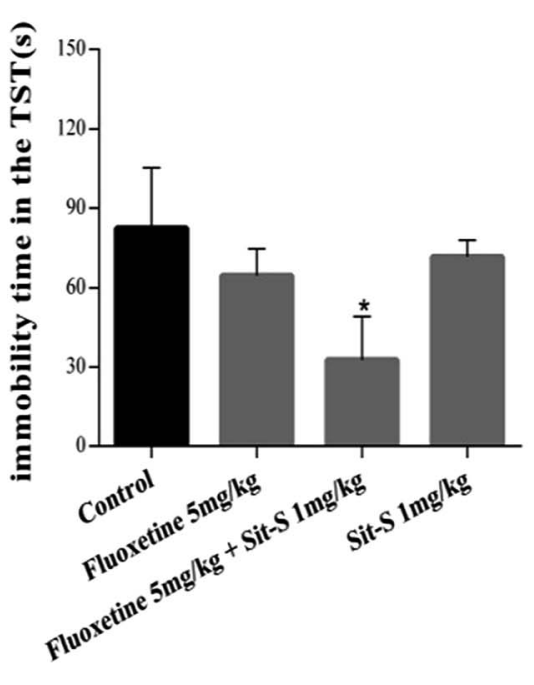

A

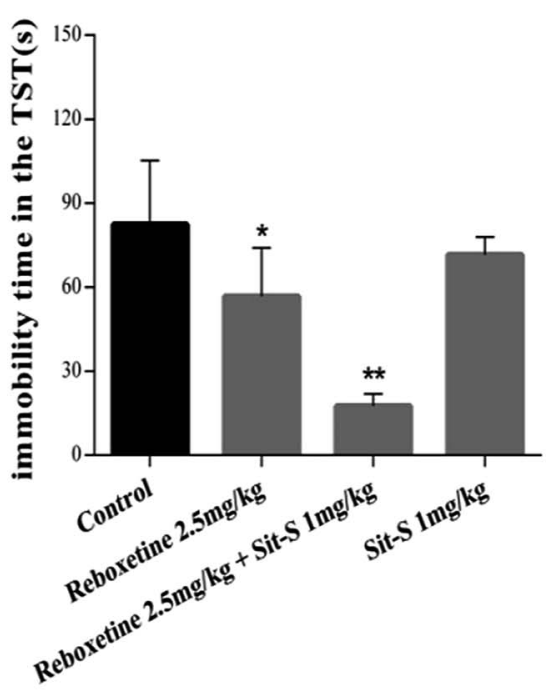

B

Fig. 4 (A) shows the antidepressant-like effect of co-administration of fluoxetine (sub-effective dose $5 \mathrm{mg} \mathrm{kg}^{-1}$, i.p.) with a sub-effective dose of Sit-S (1 mg kg $\mathrm{I}^{-1}$, i.p.) in the TST and (B) shows the antidepressant-like effect of co-administration of reboxetine (sub-effective dose $2.5 \mathrm{mg} \mathrm{kg}^{-1}$, i.p.) with a sub-effective dose of Sit-S $\left(1 \mathrm{mg} \mathrm{kg}^{-1}\right.$, i.p.) in the TST. The values represent the mean \pm SD $(n=10$ in each group), compared with the control group, $* p<0.05$ and $* * p<0.01$. 

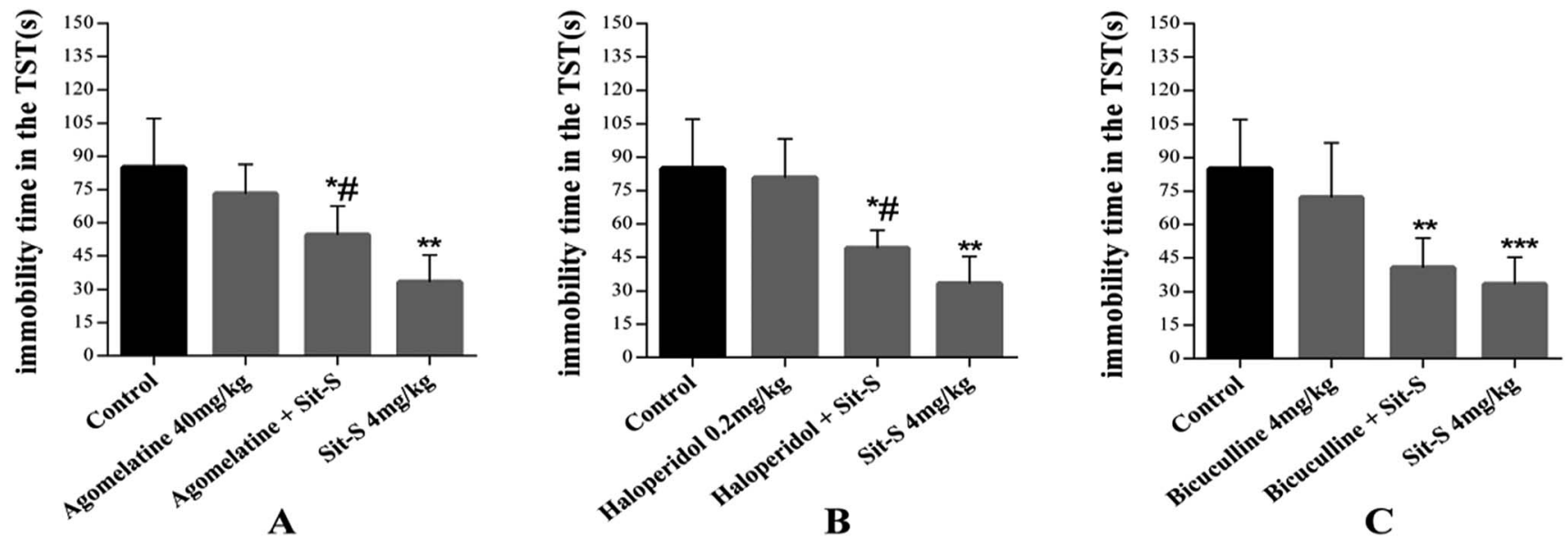

Fig. 5 (A) shows the effects of pre-treatment with agomelatine $\left(40 \mathrm{mg} \mathrm{kg}^{-1}\right.$, i.p.) on the antidepressant-like activity induced by Sit-S (4 mg kg ${ }^{-1}$, i.p.) in the TST; (B) shows the effects of pre-treatment with haloperidol $\left(0.2 \mathrm{mg} \mathrm{kg}^{-1}\right.$, i.p.) on the antidepressant-like activity induced by Sit-S ( $4 \mathrm{mg} \mathrm{kg}^{-1}$, i.p.) in the TST; and (C) shows the effects of pre-treatment with bicuculline $\left(4 \mathrm{mg} \mathrm{kg}^{-1}\right.$, i.p.) on the antidepressant-like activity induced by Sit-S $\left(4 \mathrm{mg} \mathrm{kg}^{-1}\right.$, i.p.) in the TST. The values represent the mean $\pm \mathrm{SD}(n=10$ in each group), compared with the control group, * $p<0.05$, ** $p<$ 0.01 and ${ }^{* * *} p<0.001$; compared with the Sit-S group, \#p<0.05.
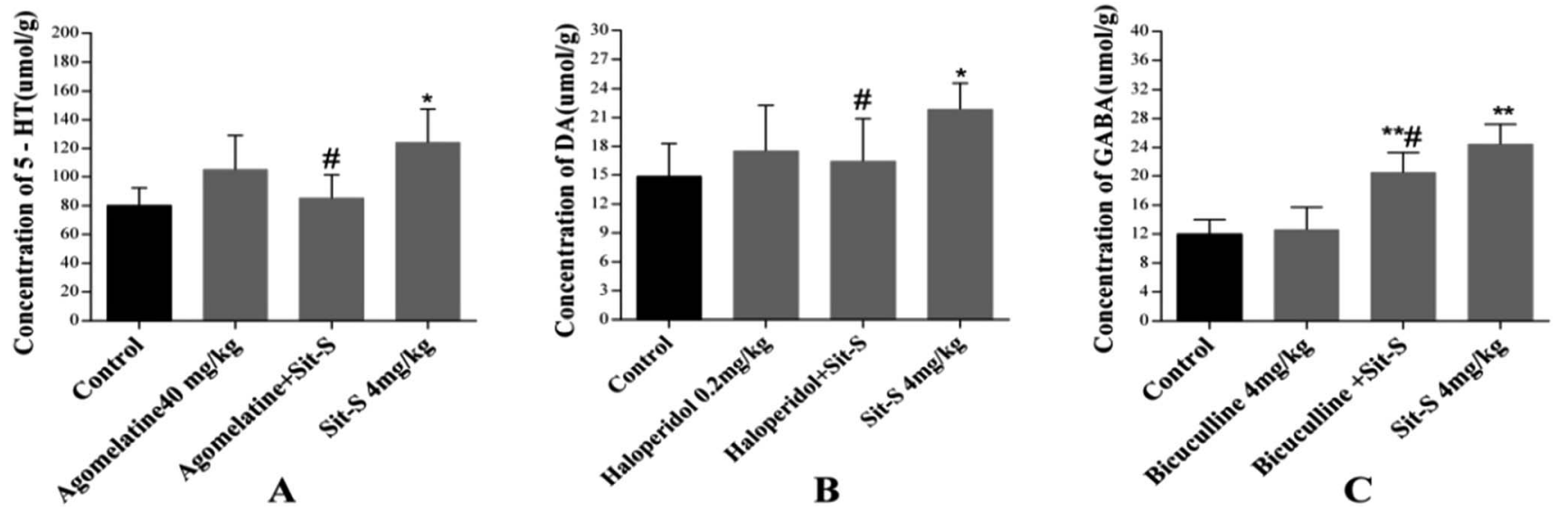

Fig. 6 Effect of co-treatment of Sit-S with agomelatine, haloperidol and bicuculline on the 5-HT, DA and GABA levels in the brains of mice exposed to the TST. The values represent the mean \pm SD $(n=10$ in each group), compared with control group, $* p<0.05$ and $* * p<0.01$; compared with the Sit-S $\left(4 \mathrm{mg} \mathrm{kg}^{-1}\right)$ group, $\# p<0.05$.

compared with that of the Sit-S group; and as shown in Fig. 6(C), the experiment revealed that bicuculline $\left(4 \mathrm{mg} \mathrm{kg}^{-1}\right)$, as an antagonist of the inhibitory neurotransmitter GABA, caused that GABA level in the mouse brain to reduce compared to that of the Sit-S group.

\section{Conclusion}

In this study, the chemical framework of Sit was structurally modified by its reaction with organic acids in dichloromethane, and the antidepressant-like activities of the obtained derivatives were screened by the TST and FST. The experiments demonstrated that Sit-S, one of the Sit derivatives, displayed the strongest antidepressant activity. Subsequently, experiments explored the neural pathways and molecular mechanisms of the antidepressant activity of Sit-S, and the results demonstrated that the antidepressant-like effect of Sit-S might be mediated by the modification of the 5-HT, DA and GABA-ergic systems.
The FST and TST are both well-known behavioral despair tests which are widely used as reliable animal models of depression, in which the immobile state of the animal induced by the stressful environment is similar to human depression. This study showed that Sit and its derivatives displayed antidepressant-like effects and that Sit-S, one of the Sit derivatives, exhibited the strongest effect in mice in the FST and TST, with sub-effective and effective doses of $1 \mathrm{mg} \mathrm{kg}^{-1}$ and $4 \mathrm{mg} \mathrm{kg}{ }^{-1}$, respectively. In order to exclude the 'false' positive effect in the behavior tests induced by the enhancement of motor activity by the drugs, the locomotor activity of Sit-S was determined and the result indicated that Sit-S $\left(4 \mathrm{mg} \mathrm{kg}^{-1}\right)$ treatment did not change the motor activity. We know that the co-administration of antidepressant drugs may display a stronger effect or faster onset speed than single drug treatment. ${ }^{22}$ In the present study, the results demonstrated that Sit-S and fluoxetine, as well as Sit-S and reboxetine, displayed synergistic effects in combination. 
Although the exact mechanism of depression remains unclear, the monoamine hypothesis is currently industry recognized as a mechanism, as patients with depression show abnormal levels of brain monoamine neurotransmitters, particularly 5-HT, NA, DA and GABA.

A long-standing theory is that the breakdown of $5-\mathrm{HT}$ in brain is critically involved in the symptoms and drug treatment of clinical depression. ${ }^{23}$ Under the guidance of the idea that the symptoms of depression are underpinned by a deficiency of 5HT in the brain, the first generation of antidepressant drugs (SSRIs) came into being, with remarkable therapeutic effect. ${ }^{24}{ }^{5-}$ HT, also known as serotonin, is a vasoactive substance and also a central neurotransmitter widely distributed in the CNS. ${ }^{25,26}$ It is thought to be a neural regulatory system that interacts with other central nervous conductions in the brain tissue and participates in the adaptation of the CNS to external stimuli, ${ }^{27}$ but also a significant regulator of emotion, sleep and other physiological activities. ${ }^{28}$ 5-HT plays a physiological role by binding and activating the receptor. With the deepening of the understanding of the 5-HT receptor, different varieties of 5-HT receptor have been found according to the transduction, affinity and function, for example 5-HT2C. There is no doubt that the increase of the 5-HT level contributes significantly to recovery form depression. ${ }^{29}$ In the present study, the fact that pretreatment with agomelatine (a 5-HT and 5-HT2C receptor antagonist) significantly reversed the antidepressant-like effect induced by Sit-S in the TST, and that Sit-S treatment significantly increased the level of 5-HT, suggests that Sit-S mediates its antidepressant effect through combination with 5-HT2C.

DA is a neurotransmitter associated with pleasure, and many studies have indicated that the biogenic amines (NA and DA) and GABA play a crucial role in the nosogenesis of depression. ${ }^{30}$ DA receptors are widely distributed in the CNS, and the most common subtypes of DA receptors are D1 and D2. ${ }^{31}$ It has been noted that $\mathrm{D} 2$ receptors are an important potential substrate for DA to participate in antidepressant effects. ${ }^{32}$ Neurochemical changes in the DA system are not got enough to understand the mechanism in animal models of depression, ${ }^{33}$ however, it is generally accepted that an increased level of DA means that depression has been alleviated. ${ }^{34}$ A previous study also showed that the hypothalamus of depressed patients with no drug improvement showed DA dysfunction, and that DA function was normal after remission. ${ }^{35}$ In this study, the results that haloperidol (a nonselective D2 receptor antagonist) pretreatment significantly reduced the antidepressant-like effect of Sit-S, and that Sit-S treatment significantly increased the DA level, suggest that the antidepressant-like effect of Sit-S might be mediated by activation of the $\mathrm{D} 2$ receptor.

Many studies have reflected that GABA is closely associated with mood disorders such as depression, anxiety and bipolar disorder. ${ }^{36}$ A previous study showed that sometimes GABA levels are significantly associated with the antidepressant clinical response rather than glutamate. ${ }^{37}$ The molecular structure of GABA is $\mathrm{NH}_{2}-\left(\mathrm{CH}_{2}\right)_{3}-\mathrm{COOH}$, and in general, the degradation of GABA causes its content to decrease in the brain. Studies have shown that GABA is significantly reduced in the animal brain in depression models, and similarly, experiments concluded that elevated GABA levels mean that depression symptoms have been relieved., ${ }^{3,1938}$ There are studies showing that increasing GABA combination with its receptors can treat depression by promoting excitatory current generation..$^{39,40}$ GABA is the significant excitatory neurotransmitter in a newly forming circuit in the process of neuronal transmission. GABA receptor (GABAR) binding produces chloride outflow and membrane depolarization, which promotes calcium entry, dendritic outgrowth and synaptogenesis, and this feature guarantees the successful transmission of excitatory information between cells. ${ }^{41,42}$ Therefore, supplementation of GABA can alleviate depression-like behavior. This study shows that pre-treatment with bicuculline (an antagonist of the inhibitory neurotransmitter GABA) slightly reduced the Sit-S antidepressant effect, however, Sit-S treatment significantly increased the GABA level, demonstrating that the antidepressant-like effect of Sit-S might partly be mediated by the modification of the GABAergic system, but this is not the main pathway. There have been studies demonstrating that 5 -HT2C receptors are also associated with the release of GABA; ${ }^{43} 5-\mathrm{HT}$ was released and activated 5-HT2C receptors, which in turn stimulated the release of GABA. $^{44}$ Therefore, the elevated GABA levels following Sit-S treatment might also be contributed to by the 5-HT receptor.

Based on this study, we believe that Sit and its derivative Sit-S might be potential materials for drug and food development against depression. To elucidate the detailed mechanisms of different receptors in the above systems, further investigations using other behavioral paradigms such as learned helplessness, chronic unpredictable stress (CUS) and social defeat stress models will be explored in our future scientific studies.

\section{Conflicts of interest}

We declare that there are no financial or other contractual agreements that might cause conflicts of interest or be perceived as causing conflicts of interest.

\section{Abbreviations}

$\begin{array}{ll}\text { Sit } & \text { Sitosterol } \\ \text { EDCI } & \text { 1-Ethyl-3-(3-dimethylaminopropyl)carbodiimide } \\ & \text { hydrochloride } \\ \text { DMAP } & \text { 4-Dimethylaminopyridine } \\ \text { Sit-T } & \text { Beta-sitosteryl 2-tetrahydrofuroate } \\ \text { Sit-P } & \text { Beta-sitosteryl } N \text {-boc-L-phenylalaninate } \\ \text { Sit-Sr } & \text { Beta-sitosteryl sorbate } \\ \text { Sit-S } & \text { Beta-sitosteryl salicylate } \\ \text { NMDA } & N \text {-Methyl-D-aspartic acid } \\ \text { FST } & \text { The forced swimming test } \\ \text { TST } & \text { The tail suspension test } \\ \text { SLT } & \text { The spontaneous locomotor activity test } \\ \text { CNS } & \text { Central nervous system } \\ \text { SSRIs } & \text { Selective serotonin reuptake inhibitors } \\ \text { SNRIs } & \text { Selective noradrenaline reuptake inhibitors } \\ \text { TCAs } & \text { Tricyclic antidepressants } \\ \text { 5-HT } & \text { Serotonin }\end{array}$


NA Noradrenaline

DA Dopamine

GABA Gamma-aminobutyric acid

\section{Acknowledgements}

The authors are grateful to the National key R\&D program (grant No. 2016YFC0500303), the Special Fund for Agro-scientific Research in the Public Interest (grant No. 201303111), and the Jilin Province Science and Technology Development Program (grant No. 20160307005YY and 20150307012YY).

\section{References}

1 F. Borsini, et al., On the role of endogenous GABA in the forced swimming test in rats, Pharmacol., Biochem. Behav., 1988, 29(2), 275-279.

2 V. Lieberknecht, et al., Antidepressant-like effect of pramipexole in an inflammatory model of depression, Behav. Brain Res., 2017, 320, 365-373.

$3 \mathrm{~W}$. Ge, et al., Study on antidepressant activity of sesquiterpenoids from ginseng root, J. Funct. Foods, 2017, 33, 261-267.

$4 \mathrm{~K}$. Pytka, et al., The role of melatonin, neurokinin, neurotrophic tyrosine kinase and glucocorticoid receptors in antidepressant-like effect, Pharmacol. Rep., 2017, 69(3), 546-554.

5 J. F. Ge, et al., Orcinol glucoside produces antidepressant effects by blocking the behavioural and neuronal deficits caused by chronic stress, Eur. Neuropsychopharmacol., 2014, 24(1), 172-180.

6 P. W. Gold, R. Machado-Vieira and M. G. Pavlatou, Clinical and biochemical manifestations of depression: relation to the neurobiology of stress, Neural Plast., 2015, 2015, 581976.

7 C. U. Correll, et al., Effects of antipsychotics, antidepressants and mood stabilizers on risk for physical diseases in people with schizophrenia, depression and bipolar disorder, World Psychiatry, 2015, 14(2), 119-136.

8 A. Hamedi, et al., Effects of $\beta$-sitosterol oral administration on the proliferation and differentiation of neural stem cells, J. Funct. Foods, 2014, 8, 252-258.

9 G. P. Zaloga, Phytosterols, Lipid Administration, and Liver Disease During Parenteral Nutrition, JPEN, J. Parenter. Enteral Nutr., 2015, 39(1 suppl.), 39S-60S.

$10 \mathrm{~S}$. S. AbuMweis, et al., Implementing phytosterols into medical practice as a cholesterol-lowering strategy: overview of efficacy, effectiveness, and safety, Can. J. Cardiol., 2014, 30(10), 1225-1232.

11 V. Vadivel, C. N. Kunyanga and H. K. Biesalski, Health benefits of nut consumption with special reference to body weight control, Nutrition, 2012, 28(11-12), 1089-1097.

12 E. Ros, Health benefits of nut consumption, Nutrients, 2010, 2(7), 652-682.

13 E. Misawa, et al., Oral ingestion of aloe vera phytosterols alters hepatic gene expression profiles and ameliorates obesity-associated metabolic disorders in zucker diabetic fatty rats, J. Agric. Food Chem., 2012, 60(11), 2799-2806.

14 B. Rubis, et al., Phytosterols in physiological concentrations target multidrug resistant cancer cells, Med. Chem., 2010, 6(4), 184-190.

$15 \mathrm{~J}$. Plat, et al., Protective role of plant sterol and stanol esters in liver inflammation: insights from mice and humans, PLoS One, 2014, 9(10), e110758.

16 S. Sakamoto, H. Nakahara and O. Shibata, Miscibility behavior of sphingomyelin with phytosterol derivatives by a Langmuir monolayer approach, J. Oleo Sci., 2013, 62(10), 809-824.

17 O. Baccouri, et al., Chemical composition and oxidative stability of Tunisian monovarietal virgin olive oils with regard to fruit ripening, Food Chem., 2008, 109(4), 743-754.

18 M. Lin, et al., Ergosteryl 2-naphthoate, An Ergosterol Derivative, Exhibits Antidepressant Effects Mediated by the Modification of GABAergic and Glutamatergic Systems, Molecules, 2017, 22(4), 565.

$19 \mathrm{H}$. Yamagata, et al., Altered plasma protein glycosylation in a mouse model of depression and in patients with major depression, J. Affective Disord., 2017, DOI: 10.1016/ j.jad.2017.08.057.

20 K. Hiraoka, et al., Pattern of c-Fos expression induced by tail suspension test in the mouse brain, Heliyon, 2017, 3(6), e00316.

$21 \mathrm{M}$. Ghasemi, et al., A role for nitrergic system in the antidepressant-like effects of chronic lithium treatment in the mouse forced swimming test, Behav. Brain Res., 2009, 200(1), 76-82.

22 T. Yan, et al., The effect of Schisandra chinensis extracts on depression by noradrenergic, dopaminergic, GABAergic and glutamatergic systems in the forced swim test in mice, Food Funct., 2016, 7(6), 2811-2819.

23 R. M. Msetfi, et al., SSRI enhances sensitivity to background outcomes and modulates response rates: a randomized double blind study of instrumental action and depression, Neurobiol. Learn. Mem., 2016, 131, 76-82.

24 E. Dale, B. Bang-Andersen and C. Sanchez, Emerging mechanisms and treatments for depression beyond SSRIs and SNRIs, Biochem. Pharmacol., 2015, 95(2), 81-97.

25 N. N. Song, et al., Enhanced dendritic morphogenesis of adult hippocampal newborn neurons in central 5-HTdeficient mice, Stem Cell Res., 2017, 19, 6-11.

26 S.-h. Lu, et al., Effects of Kaixin Powder on Expression of 5HT Receptor in Hippocampus of Depressed Rats Induced by CUMS, Chin. Herb. Med., 2015, 7(2), 150-154.

27 C. Ishikawa and T. Shiga, The postnatal 5-HT1A receptor regulates adult anxiety and depression differently via multiple molecules, Prog. Neuro-Psychopharmacol. Biol. Psychiatry, 2017, 78, 66-74.

$28 \mathrm{~J}$. D. Olivier, et al., A study in male and female 5-HT transporter knockout rats: an animal model for anxiety and depression disorders, Neuroscience, 2008, 152(3), 573584.

29 T. Sharp and P. J. Cowen, 5-HT and depression: is the glass half-full?, Curr. Opin. Pharmacol., 2011, 11(1), 45-51. 
30 N. Clausius, C. Born and H. Grunze, The relevance of dopamine agonists in the treatment of depression, Neuropsychiatr., 2009, 23(1), 15-25.

31 M. Pecina, et al., Striatal dopamine D2/3 receptor-mediated neurotransmission in major depression: Implications for anhedonia, anxiety and treatment response, Eur. Neuropsychopharmacol., 2017, 27(10), 977-986.

32 M. P. Dandekar, et al., Increased dopamine receptor expression and anti-depressant response following deep brain stimulation of the medial forebrain bundle, $J$. Affective Disord., 2017, 217, 80-88.

33 Y. Hirshler and R. Doron, Neuroplasticity-related mechanisms underlying the antidepressant-like effects of traditional herbal medicines, Eur. Neuropsychopharmacol., 2017, 27(10), 945-958.

$34 \mathrm{Z}$. Li, et al., Molecular imaging of striatal dopamine transporters in major depression-a meta-analysis, $J$. Affective Disord., 2015, 174, 137-143.

35 F. Duval, et al., Thyroid axis activity and dopamine function in major depression, Psychoneuroendocrinology, 2017, 83, 42.

36 F. Petty, GABA and mood disorders: a brief review and hypothesis, J. Affective Disord., 1995, 34(4), 275-281.

37 B. P. Brennan, et al., Acute change in anterior cingulate cortex GABA, but not glutamine/glutamate, mediates antidepressant response to citalopram, Psychiatry Res., 2017, 269, 9-16.
$38 \mathrm{~J}$. Gronli, et al., Extracellular levels of serotonin and GABA in the hippocampus after chronic mild stress in rats. A microdialysis study in an animal model of depression, Behav. Brain Res., 2007, 181(1), 42-51.

39 M. L. Brady, et al., Depolarizing, inhibitory GABA type A receptor activity regulates GABAergic synapse plasticity via ERK and BDNF signaling, Neuropharmacology, 2017, 128, 324-339.

40 N. Karim, et al., Antidepressant, anticonvulsant and antinociceptive effects of $3^{\prime}$-methoxy-6-methylflavone and 3'-hydroxy-6-methylflavone may involve GABAergic mechanisms, Pharmacol. Rep., 2017, 69(5), 1014-1020.

41 J. F. Goldberg and K. E. Burdick, Cognitive side effects of anticonvulsants, J. Clin. Psychiatry, 2001, 62(suppl 14), 2733.

42 R. Machado-Vieira, H. K. Manji and C. A. Zarate, The role of the tripartite glutamatergic synapse in the pathophysiology and therapeutics of mood disorders, Neuroscientist, 2009, 15(5), 525-539.

43 A. Chagraoui, et al., 5-HT2C receptors in psychiatric disorders: A review, Prog. Neuro-Psychopharmacol. Biol. Psychiatry, 2016, 66, 120-135.

44 T. Iwasaki, et al., Endogenously released 5-HT inhibits A and C fiber-evoked synaptic transmission in the rat spinal cord by the facilitation of GABA/glycine and 5-HT release via 5HT(2A) and 5-HT(3) receptors, Eur. J. Pharmacol., 2013, 702(1-3), 149-157. 